\title{
USING LANGUAGE AND CULTURE MATERIAL IN UKRAINIAN FOLKLORE CLASSES
}

\section{Zadorozhnya L.V. (Kharkiv)}

The methodical techniques and the methods of using language and culture material when teaching Ukrainian folklore are determined in the article. Ukrainian proverbs, sayings, songs, which reflect the vision of the Ukrainian people of female beauty, are language and culture material in this instance. The topicality of the research is caused by the extensive use of folkloric material in all modern languages with a didactic purpose and necessity of research in the ethnolinguoculturological aspect of language units that designate national and cultural stereotypes. The folklore of any nation belongs to the eternal phenomena; it is impossible to imagine the existence of a nation without it. National culture and specific features of mentality become known through folklore. Folklore helps to recreate the traits of any particular people, the development of ideas about different things. The use of proverbs in speech is an important indicator of language proficiency level. Working with proverbs and sayings helps to develop skills of speech activity. The studying of proverbs and sayings expands the students' knowledge about language, form their aesthetic taste, desire to perfect their vocabulary. It improves speech culture, speaking skills, readiness for debating in Ukrainian. The increased use of proverbs enriches the spoken and written language. The use of proverbs adds originality, expressiveness, individuality, imagery and aphoristic nature to a person's speech. Learning proverbs or sayings, students translate them into their language, comprehend and search for similar ones in their language. Discussing and comparing Ukrainian proverbs and sayings with proverbs and sayings in their native language, students develop skills in speaking, reading, and writing. Perspectives of further research are studies of the features of teaching language and culture material to foreign philological students and further development of new teaching material for the course "Ukrainian folklore”.

Key words: language and culture material, methodical technique, method, paroemia, Ukrainian folklore.

Задорожня Л.В. Використання лінгвокраїнознавчого матеріалу на заняттях 3 українського фольклору. У статті визначено методичні техніки i прийоми використання лінгвокраїнознавчого матеріалу в курсі навчання українського фольклору. Лінгвокраїнознавчий матеріал у цьому випадку становлять українські прислів'я, приказки, пісні, в яких відображені уявлення українського народу про жіночу красу. Актуальність дослідження обумовлена широким використанням фольклорного матеріалу в усіх сучасних мовах iз дидактичною метою, а також необхідністю вивчення в етнолінгвокультурологічному аспекті мовних одиниць на позначення національно-культурних стереотипів. Фольклор будь-якої нації належить до вічних явищ; без нього неможливо уявити існування народу. Через фольклор пізнається національна культура, виявляються особливості менталітету. Твори фольклору допомагають відтворювати характерні риси того чи іншого народу,

(C) Zadorozhnya L.V. 2020 
показують зміни у світогляді. Уживання в мовленні паремій - важливий показник рівня володіння мовою. Робота з прислів'ями і приказками допомагає розвивати навички мовленнєвої діяльності. Вивчення прислів”ї і приказок розширює знання студентів про мову, формує у них естетичний смак, бажання збагатити свій словниковий запас. За допомогою прислів’їв та приказок підвищується культура мовлення, удосконалюються ораторські якості, готовність до полеміки українською мовою. Активне використання прислів’їв збагачує усну й письмову мову. Використання прислів’їв і приказок надає своєрідності мовленню, виразності, індивідуальності, образності й афористичності. Ознайомившись 3 прислів'ями або приказками, студенти перекладають їх рідною мовою, осмислюють та шукають аналогічні у своїй мові. Обговорюючи та порівнюючи українські приказки та прислів'я з приказками та прислів'ями рідною мовою, студенти розвивають навички мовленнєвої діяльності, читання, письма, говоріння. Перспективи подальших досліджень полягають у вивченні особливостей викладання лінгвокраїнознавчих матеріалів іноземним студентам-філологам і у підготовці нових навчально-методичних розробок курсу «Український фольклор».

Ключові слова: лінгвокраїнознавчий матеріал, методична техніка, методичний прийом, паремія, український фольклор.

Задорожняя Л.В. Использование лингвострановедческого материала на занятиях по украинскому фольклору. В статье определены методические техники и приёмы использования лингвострановедческого материала в курсе обучения украинскому фольклору. Лингвострановедческий материал в данном случае составляют украинские пословицы, поговорки, песни, в которых отражены представления украинского народа о женской красоте. Актуальность исследования обусловлена широким использованием фольклорного материала во всех современных языках с дидактической целью, а также необходимостью изучения в этнолингвокультурологическом аспекте языковых единиц, обозначающих национально-культурные стереотипы. Фольклор любой нации принадлежит к вечным явлениям; без него невозможно представить существование народа. Через фольклор познается национальная культура, выявляются особенности менталитета. Произведения фольклора помогают воссоздавать характерные черты того или иного народа, показывают изменения в мировоззрении. Употребление в речи паремий- важный показатель уровня владения языком. Работа с пословицами и поговорками помогает развивать навыки речевой деятельности. Изучение пословиц и поговорок расширяет знания студентов о языке, формирует у них эстетический вкус, желание обогатить свой словарный запас. Посредством пословиц и поговорок повышается культура речи, совершенствуются ораторские качества, готовность к полемике на украинском языке. Активное использование пословиц обогащает устную и письменную речь. Использование пословиц и поговорок придает речи своеобразие, выразительность, индивидуальность, образность и афористичность. Ознакомившись с пословицами и поговорками, студенты переводят их на родной язык, осмысливают и ищут аналогичные в своем языке. Обсуждая и сравнивая украинские пословицы и поговорки с пословицами и поговорками на родном языке, студенты развивают навыки речевой деятельности, чтения, письма, говорения. Перспективы дальнейших исследований заключаются в изучении особенностей преподавания лингвострановедческих материалов иностранным 
студентам-филологам и в подготовке новых учебно-методических разработок курса «Украинский фольклор».

Ключевые слова: лингвострановедческий материал, методическая техника, методический приём, паремия, украинский фольклор.

Formulation of the problem in general. The effectiveness of the language and culture approach is proved by the history of its use in Ukrainian pedagogy concerning teaching foreign languages. There was an idea that the use of language and cultural information in the learning process improves the cognitive activity of students, significantly expands their communication skills, forms communicative skills and abilities, stimulates an independent study of language and helps to solve educational problems.

In the system of professional training of the future philologist and translator, the course of Ukrainian folklore takes an important place. The purpose of this course is to get to know folk art in all the aspects, to help in forming folklore, cultural and scientific competence of a future specialist. Folklore is the most precious treasure of the national culture of every nation, connected with its life and mode of life. The study of folklore is the first step in a qualitatively new process involving philological students in the learning of the history of the artistic culture of mankind. At the beginning of civilization, the art, syncretic and sacred in its original folklore form, was an integral part of everyday life. At the moment, it remains one of the most important ways of selfidentification of a personality in many manifestations.

At the Department of Language Training 2 of Institute of International Education for study and research at V.N. Karazin Kharkiv National University, there was created the textbook "Ukrainian Folklore for Foreign Students” (authors E. Valit, T. Gutnikova, L. Zadorozhnaya, G. Rudenko), whose topicality lies in the need for high-quality preparation of foreign philological students for training in specialized disciplines in Ukrainian. The textbook consists of 10 lessons. It contains scientific texts and patterns of folklore adapted for foreign students and information on literary theory. Dictionaries, which explain meanings of many words and literary terms, help to understand texts, terms, and concepts. Questions and tasks in literature, lexical and grammar exercises in the Ukrainian language help to develop and reinforce speech skills. The study of the text in every lesson is based on completing multiple exercises. Pre-text exercises are aimed to remove lexical and grammatical difficulties. The exercises, which are focused 
on mastering the vocabulary of the text, play an important role among the pre-text exercises. Post-text exercises not only control the level of understanding of the text and the effectiveness of independent work, but they also help to reinforce the lexical material, automatize language patterns and draw students' attention to the most important information. These pre-text and post-text exercises correspond to the methodological requirements: they are feasible for all students of the group in lexical and grammatical content; take into account the gradual movement from simple to complex types of work, and also appeal to various types of memory, thinking, and comprehension and activate all types of speech activity in foreign students. The course of Ukrainian folklore has an important methodological value, forms the foundation of knowledge of the science of rhetoric, which should become the base for further studying of history and theory of literature.

Taking this course, it is important for a foreign student to learn how to analyze works of Ukrainian folklore, to compare their genre features; through familiarization with folklore texts, with folkloric words, to open a special world of folk art thinking. This textbook introduces those who discover Ukraine to types and main genres of folklore: myths, tales, historical and lyrical songs, proverbs and sayings, riddles, folk drama.

The aim of the research is to determine the methodological techniques and methods of using language and culture material while teaching Ukrainian folklore. Language and culture material in this way are Ukrainian proverbs, sayings, songs, which reflect the ideas of the Ukrainian people about female beauty.

Anthropological studies are currently at their peak in modern linguistics. The materials of Ukrainian folklore have been studied from different aspects, but the linguo-cognitive direction is now the least developed. Features of the national mentality are expressed through a system of archetypical images, established in the national culture.

The topicality of the research is caused by the wide usage of folklore material in all modern languages for didactic purpose as well as the need to study the language units denoting national and cultural stereotypes in the ethnolinguoculturological aspect.

The folklore of any nation belongs to the eternal phenomena, it is impossible to imagine the existence of people without it. National culture is known through folklore, the peculiarities of mentality are revealed in it. Folklore works help recreate the characteristic features of 
any nation, the dynamics of ideas about various things. Being a combination of oral works in the process of creative collaboration, these works with traditional content reflects the representations of most people of a certain ethnic group.

Analysis of recent research and publications. Studying the ethnocultural peculiarity of the language, understanding it as a way of perceiving the world caused an uprising of new scientific directions cognitive linguistics, linguoculturology, ethnolinguistics, sociolinguistics, psycholinguistics, ethno-psycholinguistics, etc. Representatives of these scientific directions are extensively studying important ethnocultural elements: symbols, concepts, stereotypes. The study of the relationship between language and culture is based and developed in the works of A. Humboldt, A. Potebnya and others. The language was considered as a "mirror of culture" by N. Arutyunova, A. Vezhbitskaya, Yuriy Lotman, Yuriy Stepanov, N. Tolstoy, and others. Language as a cultural code of a nation, and the national culture of Ukrainians as a significant factor in the formation of the Ukrainian literary language is studied by A. Barabash-Revak, I. Golubovskaya, P. Gritsenko, N. Danilyuk, S. Ermolenko, V. Zhavoronok, M. Zhuykova, V. Kononenko, T. Kosmeda, S. Lavrinenko, L. Matsko, A. Moiseenko, L. Savchenko, A. Selivanova, N. Listen, A. Tishchenko, N. Khobzei, and others.

Learning any foreign language is impossible without learning information about the country, its culture, traditions, and customs because the language reflects the mentality of the people. Being one of the signs of a nation, its social interaction, language is the main form of expression and existence of a national culture. Many scholars have done language and culture research in the context of teaching foreign languages, in particular, E. Vereshchagin and V. Kostomarov (based on Russian as a foreign language), N. Kamenetskaya, S. Potapov (based on English), N. Borisenko (based on French), Y. Galka, A. Bronskaya, M. Redkva, O. Samusenko, O. Klimkin (based on the material of the Ukrainian language).

Linguistic and cultural studies deal with language learning through the prism of culture. The purpose of language and cultural studies is to form communicative competence during intercultural communication through an adequate understanding of speech acts and text. The main tasks of language and cultural studies according to S. Polyakova and L. Mamonova [5] are: 1. Extracting cultural information from language. 
In this case, culture is at the forefront as the main task of learning. 2. Teaching comprehension or acquaintance with a language against the background of an image similar to that present in the mind of a native speaker of a language and culture. The second task is to form an adequate understanding of the text, the use of speech structures in appropriate situations, which is the basis of communicative competence. "These concepts reflect the current trend of modern education: on the one hand, a foreign language is taught, and on the other hand, a student receives information about the cultural features of the country. At the same time, it should be noticed that in this combination a foreign language becomes a mirror of the social and cultural life of the people who are native speakers of this language" [4:131]. Language and culture material covers educational material selected according to the level of language proficiency and age characteristics of the audience, which reflects the background knowledge of native speakers as well as non-verbal forms of speech.

I. Suduk, N. Litvin, M. Titova [6: 158] distinguish the following ways of forming language and culture competence: ascertaining the meaning of nonequivalent lexemes denoting the realities of the country whose language is studied, and providing their free and conscious use in speech; the study of phraseological units that reflect specific national features, traditions, the life of the country; the study of linguistic material through familiarization with appropriate brochures, announcements, newspapers, posters, etc.; reading language and culture texts and completing assignments for their understanding and better mastering of language and culture material.

When organizing Ukrainian folklore classes for foreign students it is necessary to take into account not only the peculiarities of presentation of language and culture material and the ways of forming language and culture competence but also the methodological and psychological features of mastering a foreign language.

Presentation of the main material. Folk art is a culture-containing layer of the Ukrainian language. Proverbs and sayings as an organic part of national culture are extensive material for forming sociocultural competence. They reflect the real facts of reality and ideas about them prevailing in the mentality of the people that created and use them. Knowledge of proverbs helps to clarify the ideas of the national character of the people, expand language and cultural understanding of culture and forms views on the similarity or difference of cultures. 
Proverbs and sayings concisely and figuratively reflect the system of values, social morality, ethics, attitude to the world and other nations as well as instructions for all occasions, which are the foundation of their upbringing and educational potential. Working with proverbs and sayings, it is important to consider the following educational triad: working with folklore material in Ukrainian literature classes involves knowledge of folklore genres, reproduction of them as well as the use of folklore formulas in everyday communication. Thus working with folklore material both cognitive and affective components must be present.

Appearance does not take the first place in the system of values: «Краси на тарілці не краяти: аби з неї господиня була», «Хоч не з красою, аби з головою», "Не шукай краси, а шукай доброти», «Краса до віния, а розум до кіния», «Із лиия води не пити, аби пироги вміла пекти». Internal, moral and ethical features of female attractiveness for the Ukrainians are much more important. Virtue, dependability, homeliness determined the ideal features of a Ukrainian woman. Female beauty reveals next to men: «Красна пава пір'ям, а жінка-чоловіком». Нарру family life goes with humility, tenderness, faithfulness, intelligence for wife and with kindness, generosity, confidence and other character traits for husband: любляться як молодята; живуть як голубів пара; живуть між собою як риба з водою; живуть як в одній сорочиі; живуть як в одну дудку грають; нежонатий як вовк, оженився - як шовк; коло доброго чоловіка $i$ жінка як квітка; розумна жінка як два мішки муки, а третій пшона; жінка як кішка лашиться.

There is the understanding of attractiveness reflected in Ukrainian paroemias: black thin eyebrows, black eyes, curly and long hair, a braid. "А в рум'янці така сила, щчо всі квіти погасила», "Дарма щчо дурна, аби чорноброва», "Очі чорні, як терен», "Коса - дівоча краса», "Дівка без коси не має краси», «Коса до п'ятки - дівка до грядки», «Увіп'ються чорні брови, як п’явки, у душу»; «Вона ростом невеличка, Ще й літами молода, Руса коса до пояса, В косі стрічка голуба»; «Ой у полі три криниченьки, Любив козак три дівчиноньки: Чорнявую та білявую, Третю руду та поганую»; «Гей, дівчина, вродлива, рум'яна, чорнобрива, Оченьки-як ясоньки, Губоньки - як роженьки, Рученьки м'якесенькі, Ніженьки малесенькі, Гарная як квіточка, Любая як рибочка». 
Of course, external female beauty is not the dominant trait by which a partner was chosen. Household skills, the ability to cook, clean, embroider, give birth and bring up children, etc. in women were valued more. There is no unified image of a beautiful woman in Ukrainian folklore. It consists of individual characteristics, which include the image of some parts of the female face and body (eyes, cheeks, eyebrows, neck, hair, shape). Hair is an invariable attribute of the Ukrainian beauty. It was braided and decorated. Hair and a way of putting it were an indicator of the life status of a girl or woman. The most beautiful hair was considered black and blond. Light and red hair was not so popular in traditional Ukrainian culture. That refers to ideas about both male and female beauty. Hair was decorated with ribbons, flowers, beautiful bird feathers. "Black eyebrows", "brown eyes" and "white face", which often used in folklore, were indeed considered the standard of beauty. Moreover, this standard was applied to both men and women. If we talk about women a flush should cover white skin. The same folklore texts recorded this ideal in comparisons of a girl's face with guelder rose, berries and an apple. Speaking of body, it is important to keep in mind the lifestyle of the traditional society. Every day was filled with physical labor. Therefore, the body was considered ideal, if it was able to perform the tasks assigned to it. Both men and women had to be strong.

Based on the above conclusions, we can say that the phenomenon of "woman's beauty" is reconstructed in artistic and folk works primarily as a phenomenon involving two components: "external beauty" and "inner beauty", their correlation, their significance for defining woman as a beauty changes under the influence of sociodemographic factors.

Proverbs and sayings are an ideal material for expanding the vocabulary of students because their set is situationally adaptive and rich. The folklore material, which is used in the textbook "Ukrainian Folklore for Foreign Students” (authors E. Valit, T. Gutnikova, L. Zadorozhnaya, G. Rudenko) [1], has educational potential and the necessary didactic capacity.

The rhythmic and syntactic definition of proverbs and sayings, their composition, various stylistic figures (antonyms, homonyms, synonyms, comparisons) represent rich language material for study at different levels of training. The semantic and grammatical capacity of the proverb and saying is suitable for the implementation of developmental and educational goals of education. The use of 
paroemias makes it possible to use a wide range of teaching techniques that remove linguistic and psychological barriers in learning. Proverbs and sayings allow us to practice pronunciation, improve rhythmic and intonation skills, activate and automatize many grammatical phenomena. The use of proverbs in spontaneous speech is a standard for successful language learning. The use of paroemias trains memory and develops creative initiative. An extensive supply of folklore material demonstrates the richness of the language, its expressive properties, forms imaginative thinking, helps to express personal assessment of what is happening.

Proverbs can be used not only as illustrative material in educational practice. They can be useful in various techniques of stress relief during the lesson and diversify the routine language learning. The teacher can "use proverbs for various purposes: to illustrate phonetic and grammatical phenomena, typical communication situations, to discuss the similarities and differences of units in different languages, including a discussion on the situational use of one or another unit and understanding its figurative sense” [3: 72].

The integration of the game into the process of studying language and culture material is justified methodologically. For example, you can use communicative games that aim to ensure foreign language communication, provide for the implementation of a communicative task. Creative games also allow students to apply their imagination.

Working with foreign philological students a literature teacher can use a wide range of teaching techniques and methods that are common in the practice of teaching Ukrainian as a foreign language. Proverbs and sayings that reflect the ideas of the Ukrainians about female beauty are material for creating a coherent spoken and written speech, an element of essay and reflection. Proverbs help to study the figurative structure of the Ukrainian language in its synonymous, homonymic and antonymic richness. A comparative analysis of the figurative semantic content of proverbs and sayings of the Ukrainian language and corresponding units in the native languages of students has great potential for enhancing cognitive activity, especially in multilingual and multinational groups.

A valuable technique for using proverbs is the following task: to classify the proposed lexical material based on various properties (synonymy, antonymy, logical or semantic similarity or difference). Proverbs and sayings are the material for the semantic organization of 
illustrative material on the principle of logical connection, for which students are offered photos of girls, paintings by famous artists with the task of choosing the appropriate proverb to them. It is advisable to use the opposite method: to pick up an illustration for the proposed proverb. Proverbs are convenient material for competitions, quizzes, training battles: students can compete in the knowledge of proverbs and sayings and in the ability to use them appropriately.

For checking lexical material, the "Insert the missing word" technique is used. For the initial period of study, options with a readymade question are used, for more advanced levels - only gaps in the text presented to the student. Working with proverbs and sayings the teacher should have pedagogical imagination, philological training in the field of folk art, pedagogical tact, a desire for creative work, and possession of an arsenal of methodological techniques.

Conclusions. The usage of paroemias is an important indicator of language proficiency. After reading proverbs and sayings students translate them into their native language, comprehend and look for similar ones in their language. By discussing and comparing Ukrainian proverbs and sayings with proverbs and sayings in their native language, students develop the skills of reading, writing, and speaking. Students are ready for polemic in Ukrainian and have an opportunity to improve their oratory qualities. The active use of proverbs enriches spoken and written speech. With the help of proverbs and sayings, students expand their knowledge of the language, enrich their vocabulary. Perspectives of further research are to study the features of teaching language and culture material to foreign students-philologists in the further development of new teaching material of the course "Ukrainian folklore".

\section{ЛІТЕРАТУРА}

1. Валіт О.С., Гутнікова Т.Ю., З Задорожня Л.В., Руденко Г.Г. Український фольклор для іноземних студентів: навчальний посібник. Харків: ФЛП Тарасенко В.П., 2020. 82 с.

2. Галка Ю.М. Викладання української мови як іноземної у лінгвокраїнознавчому аспекті. URL: http://kmp.fl.kpi.ua/uk/node /45 (дата звернення: 16.03.2020).

3. Кисилева С.Н. К вопросу об использовании единиц фразеологии и афористики в учебном процессе на подготовительном факультете. Русский язык для студентов иностренцев: сб. метод. статей. М.: Русский язык, 1984. № 23. С. 71-78. 
4. Мороз Л. Вивчення лінгвокраїнознавчого аспекту в процесі оволодіння іноземними мовами. Нова педагогічна думка. 2014. № 2. URL: http://nbuv.gov.ua/UJRN/Npd_2014_2_40 (дата звернення: 15.03.2020).

5. Полякова С.В. Лінгвокраїнознавство - освіта засобами іноземної мови. URL: http://www.rusnauka.com/ESPR_2006/Philologia/10_ poljakova\%20s.v..doc.htm (дата звернення: 15.03.2020).

6. Судук I., Литвин Н., Титова М. Шляхи формування лінгвокраїнознавчої компетенції на заняттях з української мови як іноземної. Вісник ОНУ. Серія Філологічна. 2016. С. 153-159.

7. Українські прислів'я і приказки / упорядник Т.М. Панасенко. Харків: Фоліо, 2004. 351 c.

8. Шеремета В.П. Національно-культурні стереотипи мовообразу жінки в українських народних піснях: дис. ... канд. філол. наук: 10.02.01 українська мова / Нац. пед. університет ім. М.П. Драгоманова. Київ, 2017. URL: https://npu.edu.ua/images/file/vidil_aspirant/avtoref/\%D0\% 94_26.053.25/Sheremeta.pdf (дата звернення: 16.03.2020).

\section{REFERENCES}

Galka, Yu.M. (2000). Vykladannya ukrayinskoyi movy yak inozemnoyi u lingvokrayinoznavchomu aspekti [Teaching Ukrainian as a foreign language in the aspect of culture-oriented linguistics.]. Available at: http://kmp.fl .kpi.ua/uk/node/45 [Accessed 16 March 2020] [in Ukrainian].

Kiseleva, S.N. (1984). K voprosu ob ispolzovanii edinic frazeologii i aforistiki $\mathrm{v}$ uchebnom processe na podgotovitelnom fakultete [On the use of units of phraseology and aphoristics in the teaching process at the preparatory faculty]. Russkiy yazyik dlya studentov inostrentsev [Russian for foreign students]. Moscow: Russkij jazyk, 23, pp. 71-78 [in Russian].

Moroz, L. (2014). Vyvchennya lingvokrayinoznavchogo aspektu v procesi ovolodinnya inozemnymy movamy [Study of the aspect of culture-oriented linguistics in the process of mastering foreign languages]. Nova pedagogichna dumka [New pedagogical thought], 2. Available at: http://nbuv.gov.ua/UJRN/Npd_2014_2_40 [Accessed 15 March 2020] [in Ukrainian].

Panasenko, T.M. (2004). Ukrainski pryslivia i prykazky [Ukrainian proverbs and sayings]. Kharkiv: Folio [in Ukrainian].

Polyakova, S.V. (2006). Lingvokrayinoznavstvo - osvita zasobamy inozemnoyi movy [Culture-oriented linguistics as education by means of a foreign language]. Available at: http://www.rusnauka.com/ESPR_2006/Philologia/ 10_poljakova\%20s.v.doc.htm [Accessed 15 March 2020] [in Ukrainian].

Sheremeta, V.P. (2017). Natsionalno-kulturni stereotypy movoobrazu zhinky v ukrainskykh narodnykh pisniakh [National and cultural stereotypes of women's language in Ukrainian folk songs]. Candidate's thesis. Kyiv: 
National Pedagogical Dragomanov University. Available at: https://npu.edu.ua/images/file/vidil_aspirant/avtoref/\%D0\%94_26.053.25/

Sheremeta.pdf [Accessed 16 March 2020] [in Ukrainian].

Suduk, I., Lytvyn, N. and Tytova, M. (2016). Shlyahy formuvannya lingvokrayinoznavchoyi kompetenciyi na zanyattyax z ukrayinskoyi movy yak inozemnoyi [Ways of formation of linguistic and country specific competence in classes of Ukrainian as a Foreign Language]. Visnyk ONU [ONU Bulletin], Philological Series, pp. 153-159 [in Ukrainian].

Valit, O.S., Gutnikova, T.Yu., Zadorozhnya, L.V. and Rudenko, G.G. (2020). Ukrayinskyj folklor dlya inozemnyx studentiv [Ukrainian folklore for foreign students]. Kharkiv: FLP Tarasenko V.P. [in Ukrainian].

Стаття надійшла до редакиії: 25.02.2020

Задорожня Людмила Вікторівна, старший викладач кафедри мовної підготовки 2 Навчально-наукового інституту міжнародної освіти Харківського національного університету імені В.Н. Каразіна (61022, Харків, майдан Свободи, 4); e-mail: lludm8139@gmail.com; orcid: http://orcid.org/0000-0001-6607-3550

Задорожняя Людмила Викторовна, старший преподаватель кафедры языковой подготовки 2 Учебно-научного института международного образования Харьковского национального университета имени В.Н. Каразина (61022, Харьков, площадь Свободы, 4); e-mail: lludm8139@gmail.com; orcid: http://orcid.org/0000-0001-6607-3550

Liudmyla Zadorozhnya, Assistant Professor, Language Training Department 2, Institute of International Education for Study and Research, V.N. Karazin Kharkiv National University (61022, Kharkiv, 4 Svoboda Square); e-mail: lludm8139@gmail.com; orcid: http://orcid.org/0000-00016607-3550. 